\title{
Utilization of Potato Flour in Making Pukis Cake
}

\author{
Dikki Zulfikar ${ }^{1}$, Wiwik Gusnita ${ }^{2}$, \\ 1,2 Ilmu Kesejahteraan Keluarga \\ Faculty of Tourism and Hospitality, Universitas Negeri Padang \\ Jl. Dr. Hamka, Padang, 25131, West Sumatera, Indonesia \\ Email : dikkizulfikar@fpp.unp.ac.id
}

\begin{abstract}
This research is motivated by the use of potato flour in food processing is still small. Potato flour has a high enough nutritional value for protein. This study aims to analyze the effect of $50 \%$ potato flour substitution on the quality of paint in terms of volume, shape, color, aroma, texture and taste. This type of research is an experiment with three repetitions. To get the results of the study organoleptic tests were carried out by 15 panelists, namely students of the D3 and S1 at the culinary department. Organoleptic test results with 3 repetitions showed that the quality of the use of potato starch in the manufacture of paint was volume swell, same and semicircular shape, yellow color, aroma of vanilla, and potato starch, porous texture, sweet taste and taste of potato starch.
\end{abstract}

Keywords: Potato Flour, Painting, Quality

\begin{abstract}
Abstrak
Penelitian ini dilatarbelakangi oleh penggunaan tepung kentang dalam pengolahan makanan yang masih kecil. Tepung kentang memiliki nilai gizi protein yang cukup tinggi. Penelitian ini bertujuan untuk menganalisis pengaruh substitusi tepung kentang $50 \%$ terhadap kualitas cat dalam hal volume, bentuk, warna, aroma, tekstur dan rasa. Jenis penelitian ini adalah eksperimen dengan tiga pengulangan. Untuk mendapatkan hasil studi tes organoleptik dilakukan oleh 15 panelis, yaitu mahasiswa D3 dan S1 di jurusan kuliner. Hasil uji organoleptik dengan 3 ulangan menunjukkan bahwa kualitas penggunaan tepung kentang dalam pembuatan cat adalah volume yang membengkak, bentuknya sama dan berbentuk setengah lingkaran, warna kuning, aroma vanili dan tepung kentang, tekstur berpori, rasa manis dan rasa tepung kentang .
\end{abstract}

Kata kunci: kuliner, pariwisata, perhotelan 


\section{Introduction}

Potatoes (Solanum tuberosum L) are tubers that are rich in carbohydrates and can be used as food substitutes for staple foods. Potatoes have become one of the world's staple foods because they are ranked third in the crop consumed by the world community after rice and wheat (Internationale Potato Center, 2013). Potato tubers do not contain fat, cholesterol but contain carbohydrates, sodium, protein, vitamin $\mathrm{A}$, vitamin $\mathrm{C}$, calcium, iron and vitamin B6 content, which is quite high when compared to rice.

Processing potatoes by making flour is one of the efforts to diversify food ingredients and can extend the durability and shelf life of potatoes. However, not so many people understand the use of potato flour. One way to optimize the potential of potato starch is to use it in making paint.

Paintings are quite popular with the people of Indonesia from the past until now, seen from the number of paint sellers on the roadside. Painting processing techniques using the sponge cake method. According to Bogasari Baking Center (2015), "the sponge cake method is egg and sugar beaten at high speed until fluffy after that enter the flour gradually with a low-speed mixer, when using margarine, thaw or shake first, then enter slowly until evenly distributed.

Paintings are quite popular with the people of Indonesia from the past until now, seen from the number of paint sellers on the roadside. Painting processing techniques using the sponge cake method. According to Bogasari Baking Center (2015), "the sponge cake method is egg and sugar beaten at high speed until fluffy after that enter the flour gradually with a low-speed mixer, when using margarine, thaw or shake first, then enter slowly until evenly distributed.

Based on research three times repetition (P1) (P2) and (P3), the author will explain one by one the quality of the use of potato starch in the manufacture of paint. After the data is collected, then it is processed and analyzed. The data analysis technique used in this study is the percentage technique

\section{Method/Metode}

This type of research is an experiment with three repetitions. Getting the results of the study, organoleptic tests were carried out by 15 panelists, namely students of the D3 and $\mathrm{S} 1$ at the culinary department.

\section{Result and Discussion}

Based on table 1 above regarding the volume of expanding use of potato flour in the making pukis cake of the first repetition showed 11 panelists (73\%) thought the volume proofing and 4 panelists (27\%) thought the volume was quite proofing. The second repetition shows 12 panelists $(80 \%)$ thought the volume proofing and 3 panelists (20\%) thought the volume was quite proofing. The third repetition shows that 15 panelists $(100 \%)$ thought the volume was proofing .

Table 1 Description of Organoleptic Test Data of Volume Quality Developing Use of Potato Flour in Making pukis cake

This is an open access article distributed under the Creative Commons 4.0 Attribution License, which permits unrestricted use, distribution, and reproduction in any medium, provided the original work is properly cited. C2017 by author and Universitas Negeri Padang. 


\begin{tabular}{|c|c|c|c|c|c|c|c|}
\hline \multirow[t]{2}{*}{ Quality } & \multirow[t]{2}{*}{ Description } & \multicolumn{2}{|c|}{ Repeatation I } & \multicolumn{2}{|c|}{$\begin{array}{l}\text { Repeatation } \\
\text { II }\end{array}$} & \multicolumn{2}{|c|}{$\begin{array}{l}\text { Repeatation } \\
\text { III }\end{array}$} \\
\hline & & $\mathrm{P}$ & $\%$ & $\mathrm{P}$ & $\%$ & $\mathrm{P}$ & $\%$ \\
\hline \multirow{5}{*}{ Volume } & Proofing & 11 & 73 & 12 & 80 & 15 & 100 \\
\hline & Quite Proofing & 4 & 27 & 3 & 20 & - & - \\
\hline & Less Proofing & - & - & - & - & - & - \\
\hline & No Proofing & - & - & - & - & - & - \\
\hline & Jumlah & 15 & 100 & 15 & 100 & 15 & 100 \\
\hline
\end{tabular}

From the description of the organoleptic test above, it can be concluded that the highest percentage for the volume quality of using potato flour to increase the quality of volume was found in the third repetition of 15 panelists (100\%). For more details on the results of the volume quality proofing the use of potato starch in the manufacture of paint can be seen, graphs in Figure 15 as follows:

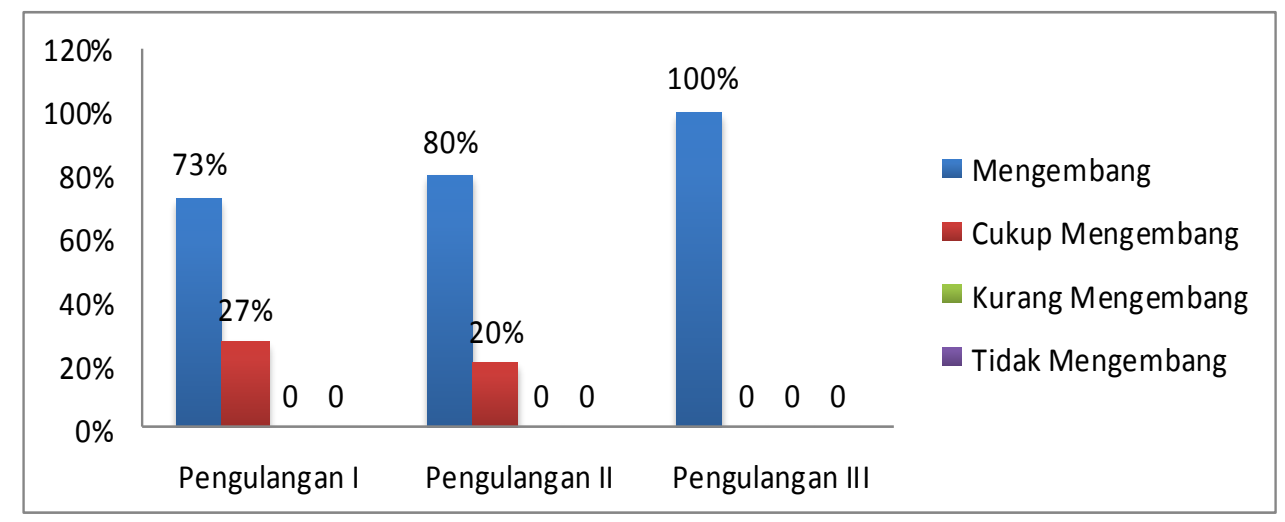

Figure 1. Graph Description of Organoleptic Test Data of Volume Quality Expanding Use of Potato Flour in Making Paintings

The results of the repetition of the uniform quality of the use of potato starch in the manufacture of paint can be seen in table 2 as follow:

Table 2 Description of Organoleptic Test Data on the Quality of Uniform Forms in the Use of Potato Flour in Making Paintings

\begin{tabular}{clccccccc}
\hline \multirow{2}{*}{ Quality } & Deskripsi & \multicolumn{2}{c}{ Pengulangan I } & \multicolumn{2}{c}{ Pengulangan II } & \multicolumn{2}{c}{$\begin{array}{c}\text { Pengulangan } \\
\text { III }\end{array}$} \\
\cline { 2 - 8 } & & $\mathrm{P}$ & $\%$ & $\mathrm{P}$ & $\%$ & $\mathrm{P}$ & $\%$ \\
\hline \multirow{5}{*}{ Shape } & Same shape & 8 & 53 & 12 & 80 & 13 & 87 \\
\cline { 2 - 8 } & $\begin{array}{l}\text { Quite same } \\
\text { shape }\end{array}$ & 3 & 20 & 3 & 20 & 2 & 13 \\
\cline { 2 - 8 } & $\begin{array}{l}\text { Less Enough } \\
\text { same shape }\end{array}$ & 4 & 27 & - & - & - & - \\
\cline { 2 - 8 } & $\begin{array}{l}\text { Not Same } \\
\text { shape }\end{array}$ & - & - & - & - & - & - \\
\cline { 2 - 8 } & Jumlah & $\mathbf{1 5}$ & $\mathbf{1 0 0}$ & $\mathbf{1 5}$ & $\mathbf{1 0 0}$ & $\mathbf{1 5}$ & $\mathbf{1 0 0}$ \\
\hline
\end{tabular}

Based on table 2 above regarding the uniform shape of the use of potato starch in the making pukis cake of the first repetition, 8 panelists $(53 \%)$ thought the form was the 
same shape, 3 panelists (20\%) thought the shape was Less Enough same shape and 4 panelists (27\%) same thoughtless shape. The second repetition shows 12 panelists (80\%) thought the form was the same shape and 3 panelists (20\%) thought the form was quite the same shape. The third repetition shows 13 panelists (87\%) thought the form was quite the same shape and 2 panelists thought the form was quite the same shape.

From the description of the organoleptic test above it can be concluded that the highest percentage for shape quality Based on table 5 above regarding the same shape of the use of potato flour in the making of the first repetition, 8 panelists (53\%) found same shape, 3 panelists (20\%) argued that the forms quite shaped and 4 panelists (27\%) thought the forms were less enough shape. The second repetition shows 12 panelists (80\%) thought the form was the same shape and 3 panelists $(20 \%)$ thought the form was quite the same shape. The third repetition shows 13 panelists $(87 \%)$ thought the form was the same shape and 2 panelists thought the form was quite the same shape.

The same shape use of potato flour on the quality found in the third repetition of 13 panelists (87\%). For more details, the results of the same quality of the use of potato starch in the manufacture can be seen in graph 16 as follow.

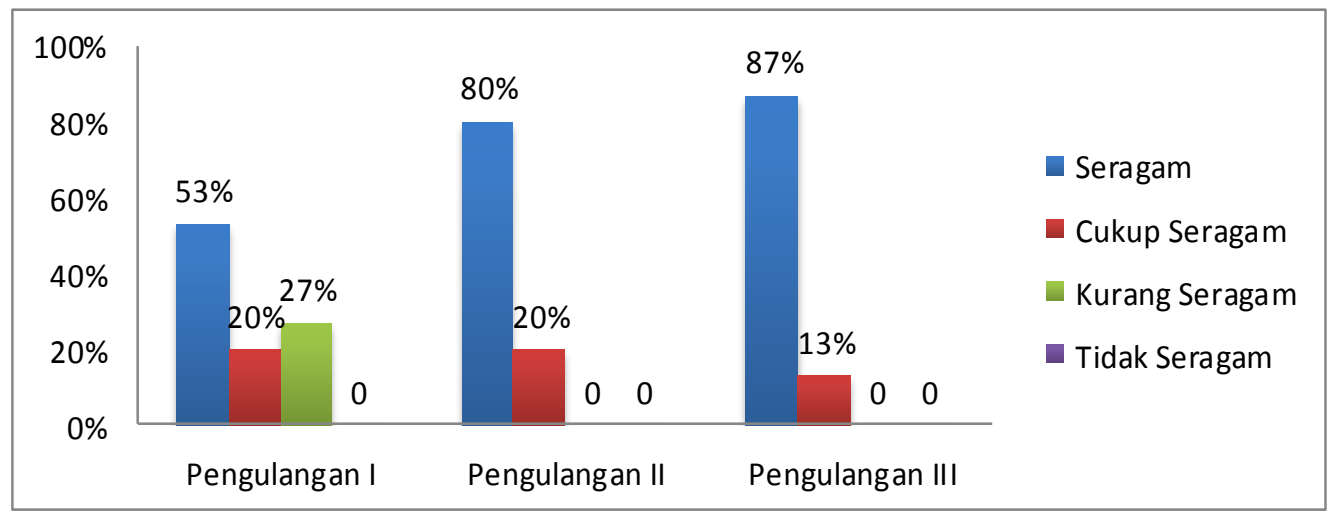

Figure 2. Graph Description of Organoleptic Test Data for Quality shape Use of Potato Flour in making pukis cake

The results of the repetition of the yellow color quality of the use of potato starch in the manufacture of paint can be seen in Table 3 as follows:

Table 3 Description of Color Quality Organoleptic Test Data Use of Potato Flour in Making Pukis cake

\begin{tabular}{clccccccc}
\hline \multirow{2}{*}{ Quality } & \multirow{2}{*}{ Description } & \multicolumn{2}{c}{ Repetition I } & \multicolumn{2}{c}{ Repetition II } & \multicolumn{2}{c}{ Repetition III } \\
\cline { 2 - 9 } & & $\mathrm{P}$ & $\%$ & $\mathrm{P}$ & $\%$ & $\mathrm{P}$ & $\%$ \\
\hline \multirow{3}{*}{ Color } & Yellow & 12 & 80 & 14 & 93 & 15 & 100 \\
\cline { 2 - 9 } & Quite Yellow & 3 & 20 & 1 & 7 & - & - \\
\cline { 2 - 8 } & Less yellow & - & - & - & - & - & - \\
\cline { 2 - 8 } & Not yellow & - & - & - & - & - & - \\
\cline { 2 - 8 } & Jumlah & 15 & 100 & 15 & 100 & 15 & 100 \\
\hline
\end{tabular}

Based on table 3 above regarding the color of the use of potato starch in the making pukis cake of the first repetition, 12 panelists (80\%) thought yellow, and 3 panelists (20\%) thought the color was quite yellow. The second repetition showed 14 panelists (93\%) thought the color yellow and 1 panelist (7\%) thought the color was quite yellow. The third repetition shows 15 panelists (100\%) thought yellow. 
From the description of the organoleptic test above, it can be concluded that the highest percentage for the quality of the yellow color of the use of potato starch to the quality of paint was found in the third repetition of 15 panelists $(100 \%)$. For more details about the results of the yellow color quality of the use of potato starch in the manufacture of paint can be seen graphically in Figure 18 as follows:

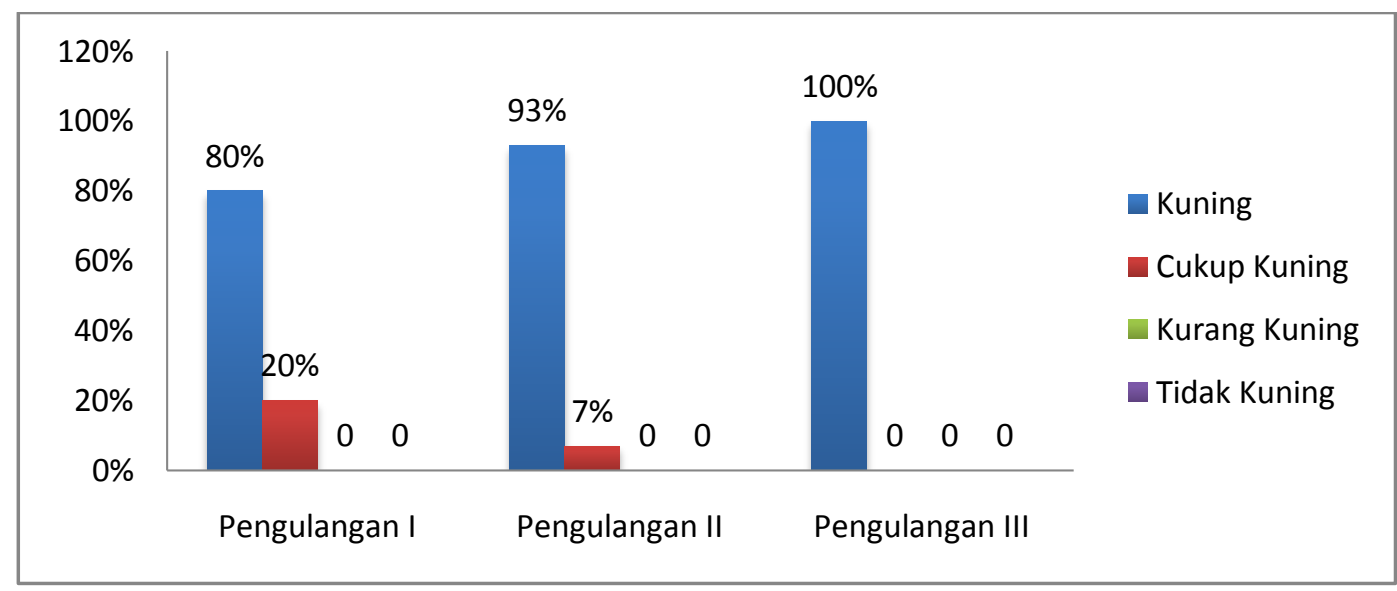

Figure 3. Graph Description of Organoleptic Test Data for Quality color Use of Potato Flour in making pukis cake

The results of the repetition of the quality of the aroma of vanilla using potato starch in the manufacture of paint can be seen in Table 8 as follows:

Table 4 Description of Aroma Quality Organoleptic Test Data Use of Potato Flour in Making Pukis cake

\begin{tabular}{clcccccc}
\hline \multirow{2}{*}{ Quality } & \multirow{2}{*}{ Description } & \multicolumn{2}{c}{ Repetition I } & \multicolumn{2}{c}{ Repetition II } & \multicolumn{2}{c}{ Repetition III } \\
\cline { 2 - 8 } & & $\mathrm{P}$ & $\%$ & $\mathrm{P}$ & $\%$ & $\mathrm{P}$ & $\%$ \\
\hline \multirow{5}{*}{ Aroma } & Vanila Aroma & 5 & 33 & 9 & 60 & 14 & 93 \\
\cline { 2 - 8 } & Quite Vanila Aroma & 3 & 20 & 3 & 20 & 1 & 7 \\
\cline { 2 - 8 } & Less Vanila Aroma & 4 & 27 & 1 & 7 & - & - \\
\cline { 2 - 8 } & No Vanila Aroma & 3 & 20 & 2 & 13 & - & - \\
\cline { 2 - 8 } & Jumlah & 12 & 100 & 13 & 100 & 15 & 100 \\
\hline
\end{tabular}

Based on table 8 above regarding the aroma of vanilla, the use of potato flour in the making pukis cake of the first repetition shows 5 panelists $(33 \%)$ thought the aroma of vanilla, 3 panelists $(20 \%)$ thought it was a quite vanilla aroma, 4 panelists $(27 \%)$ thoughtless vanilla aroma and 3 panelists (20\%) thought no vanilla aroma. The second repetition showed 9 panelists $(60 \%)$ thought the aroma was vanilla, 3 panelists $(20 \%)$ thought it was quite vanilla, 1 panelist (7\%) thought it wasn't vanilla scent and 2 panelists $(13 \%)$ thought it wasn't scent vanilla. The third repetition shows that 14 panelists $(93 \%)$ thought the aroma of vanilla and 1 panelist (7\%) thought that it was quite vanilla. 


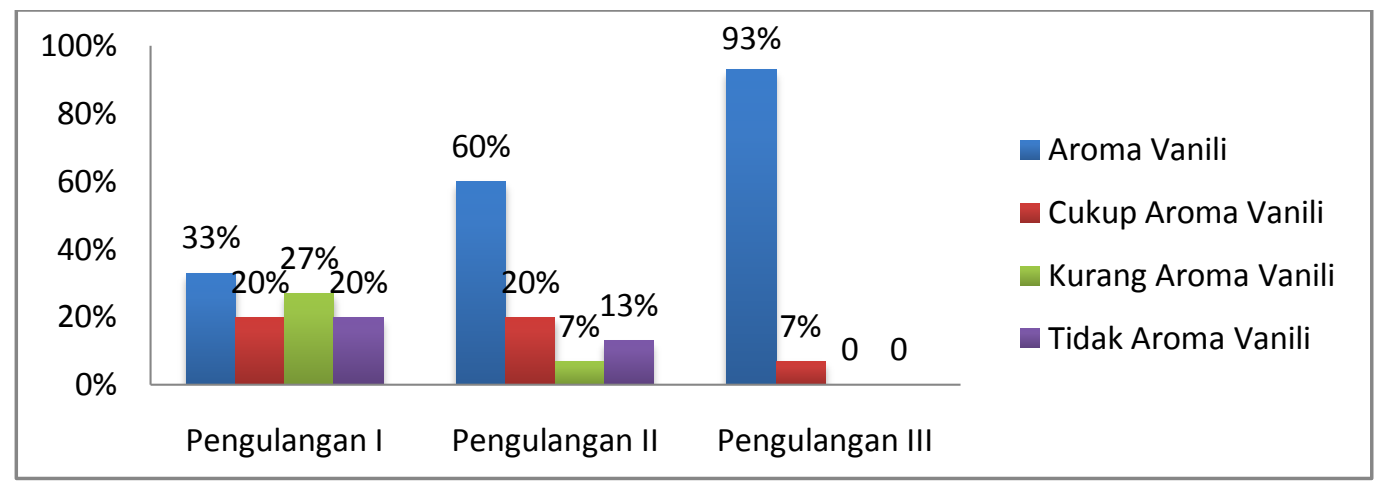

Figure 4. Graph Description of Organoleptic Test Data for Quality color Use of Potato Flour in making pukis cake

From the description of the organoleptic test above, it can be concluded that the highest percentage for the quality of the aroma of vanilla using potato starch to the quality of paint was found in the third repetition of 14 panelists (97\%). For more details about the results of the quality of the aroma of vanilla using potato starch in the manufacture of paint can be seen in the graph 19 as follows:

The results of the repetition of the quality of the porous texture of the use of potato starch in the manufacture of paint can be seen in Table 9 as follows:

Table 5 Description of Texture Quality Organoleptic Test Data Use of Potato Flour in Making Pukis cake

\begin{tabular}{clcccccc}
\hline \multirow{3}{*}{ Quality } & \multirow{2}{*}{ Description } & \multicolumn{2}{c}{ Repetition I } & \multicolumn{2}{c}{ Repetition II } & \multicolumn{2}{c}{ Repetition } \\
\cline { 2 - 8 } & & $\mathrm{P}$ & $\%$ & $\mathrm{P}$ & $\%$ & $\mathrm{P}$ & $\%$ \\
\hline \multirow{5}{*}{ Texture } & Porous texture & 11 & 73 & 10 & 67 & 13 & 87 \\
\cline { 2 - 8 } & Quite porous texture & 1 & 7 & 3 & 20 & 2 & 13 \\
\cline { 2 - 8 } & Less Porous texture & 3 & 20 & 2 & 13 & - & - \\
\cline { 2 - 8 } & No Porous texture & - & - & - & - & - & - \\
\cline { 2 - 8 } & Jumlah & 15 & 100 & 15 & 100 & 15 & 100 \\
\hline
\end{tabular}

Based on table 5 above regarding the porous texture of the use of potato flour in the making of the first repetition, 11 panelists $(73 \%)$ thought that the texture was porous, 1 panelist $(20 \%)$ thought the texture was quite porous, and 3 people panelists $(20 \%)$ found the texture to be less porous. The second repetition showed 10 panelists $(67 \%)$ thought the texture was porous, 3 panelists $(20 \%)$ thought the texture was quite porous and 2 people $(13 \%)$ thought the texture was less porous. The third repetition showed 13 panelists (87\%) thought the texture was porous and 2 panelists (13\%) thought the texture was porous enough 


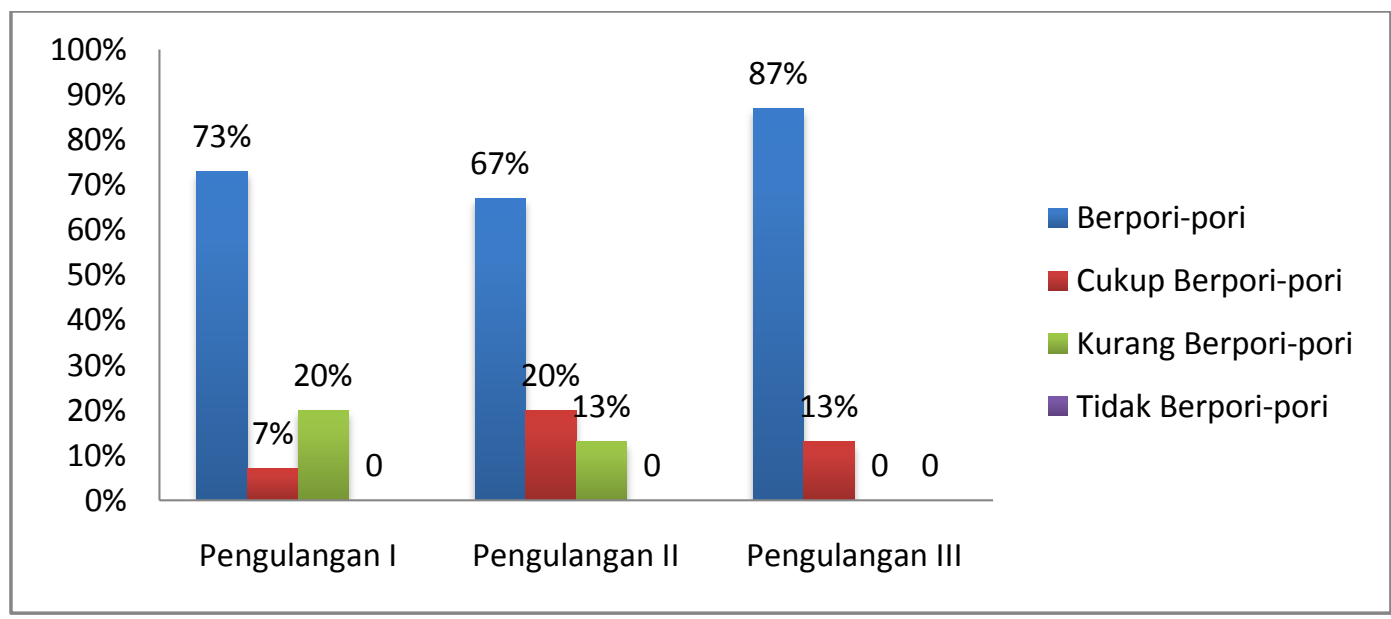

Figure 5. Graph Description of Organoleptic Test Data for Quality texture Use of Potato Flour in making pukis cake

From the description of the organoleptic test above, it can be concluded that the highest percentage for the quality of the porous texture of the use of potato starch to the quality of paint was found in the third repetition of 13 panelists (87\%). For more details about the quality of the porous texture of the use of potato starch in the manufacture of paint can be seen in graph 20 as follows:

The results of the repetition of the quality of sweetness in the use of potato starch in the making making pukis cake can be seen in table 5as follows:

Table 6 Description of Organoleptic Test Data for Sweet Taste Quality of Potato Flour Use in Making Pukis Cake

\begin{tabular}{|c|c|c|c|c|c|c|c|}
\hline \multirow[t]{2}{*}{ Quality } & \multirow[t]{2}{*}{ Description } & \multicolumn{2}{|c|}{$\begin{array}{l}\text { Repetition } \\
\text { I }\end{array}$} & \multicolumn{2}{|c|}{$\begin{array}{l}\text { Repetition } \\
\text { II }\end{array}$} & \multicolumn{2}{|c|}{$\begin{array}{l}\text { Repetition } \\
\text { III }\end{array}$} \\
\hline & & $\mathrm{P}$ & $\%$ & $\mathrm{P}$ & $\%$ & $\mathrm{P}$ & $\%$ \\
\hline \multirow{5}{*}{ Rasa } & Sweet & 12 & 80 & 14 & 93 & 15 & $0^{10}$ \\
\hline & Quite sweet & 2 & 13 & 1 & 7 & - & - \\
\hline & Lacking sweet & 1 & 7 & - & - & - & - \\
\hline & No sweet & - & - & - & - & - & - \\
\hline & Jumlah & 15 & 10 & 15 & 10 & 15 & $\begin{array}{ll}10 \\
0\end{array}$ \\
\hline
\end{tabular}

Based on table 10 above regarding the sweet taste of the use of potato flour in the making puking cake of the first repetition, 12 panelists (80\%) thought it was sweet, 2 panelists $(13 \%)$ thought it was quite sweet, and 1 panelist $(7 \%)$ thought lacking sweetness. The second repetition shows that 14 panelists (93\%) thought that the taste was sweet and 1 panelist (7\%) thought that the taste was quite sweet. The third repetition shows that 15 panelists $(100 \%)$ thought sweet.

From the description of the organoleptic test above, it can be concluded that the highest percentage for the sweet taste quality of using potato starch to the quality of paint was found in the third repetition of 15 panelists $(100 \%)$. For more details about the 
results of the sweet taste quality of the use of potato starch in the manufacture of paint can be seen graphs in Figure 21 as follows:

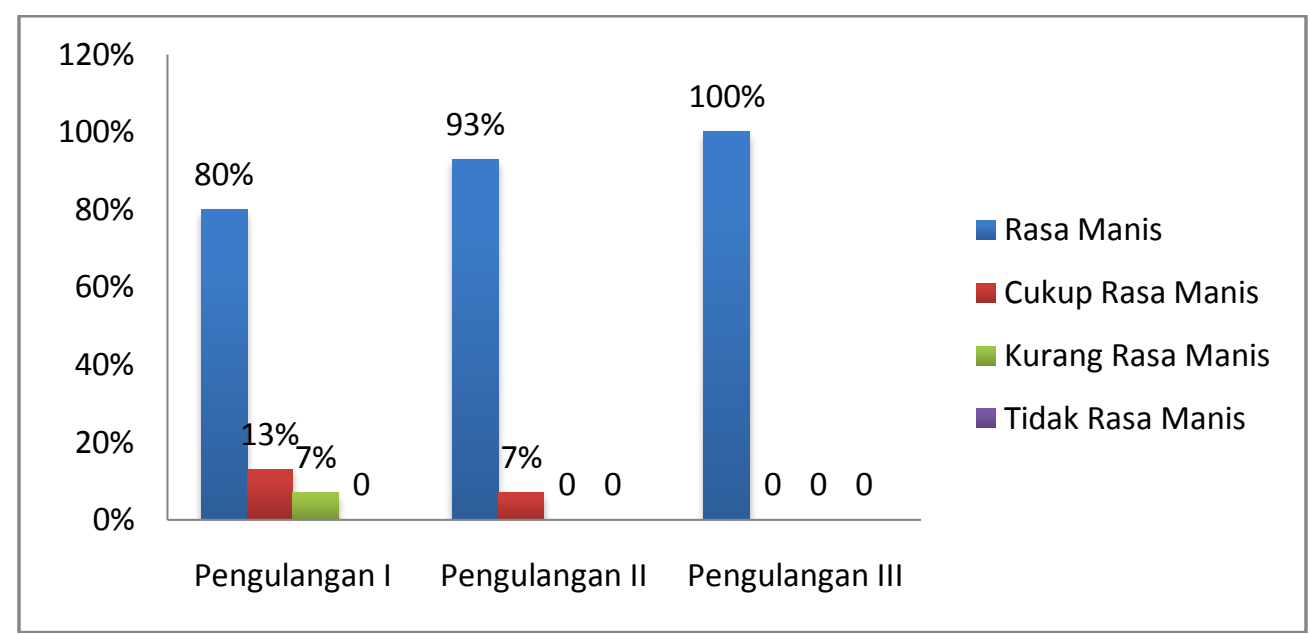

Figure 6. Graph Description of Organoleptic Test Data for Taste Use of Potato Flour in making pukis cake

\section{Conclusion}

Based on research that has been done, 3 (three) repetition and then proceeds with organoleptic tests and data analysis can be concluded as follows: The volume quality of potato pukis cake is inflated, with the highest percentage that is found in repetition III $(100 \%)$. The quality of the shape of potato cake is uniform, with the highest percentage being in repetition III $(87 \%)$. The quality of the color of potato cake is the highest percentage that is found in repetition III (100\%). The aroma of potato cake is vanilla aroma; the use of potato flour on the quality of the paint is found in the third repetition $(97 \%)$.

\section{Reference}

Buckle, K.K, dkk,(1987). Ilmu Pangan, Jakarta Universitas Indonesia Press.

Lingga, (2005). Teknologi Pengolahan Pisang, Jakarta Gramedia

Direktorat Gizi Departemen Kesehatan RI ( 2008). Daftar Komposisi Bahan Makanan, Jakarta Karya Aksara.

Desrosier, N. W, (2008). Teknologi Pengawetan Pangan. Jakarta Universitas Indonesia. Press

Harris, (1989). Tekologi Pengolahan Pangan, Jakarta Gramedia

Hernawati Fajiarningsih, 2013. "Pengaruh Penggunaan Komposit Tepung Kentang

(Solanum Tuberosum L) Terhadap Kualitas Cookies". Skripsi Semarang:

Fakultas Teknik, Universitas Negeri Semarang

Suyanti, (2006). Teknologi Pengolahan Pisang. Jakarta Gramedia. 
Suliantari dan Winiati Puji Rahayu, (1990). Teknologi Fermentasi Biji-bijian dan Umbiumbian, Bogor Dirjen Pangan dan Gizi IPB Bogor.

Suyanti dan Ahmad, (2006). Budi Daya Pisang, Pengolahan dan Prospek Pasar, Jakarta, Penebar Swadaya.

Sutrisno Kaswara. 2007. Modul Teknologi Pengolahan Umbi-umbian (Online), (https://www.sefast.ipb.ac.id) 